ISSN 1392-3196 / e-ISSN 2335-8947

Zemdirbyste-Agriculture, vol. 103, No. 1 (2016), p. 107-114

DOI 10.13080/z-a.2016.103.014

\title{
Chemical composition and nutritional value of seeds of Lupinus luteus L., L. angustifolius L. and new hybrid lines of L. angustifolius L.
}

\author{
Elena BARTKIENE ${ }^{1}$, Vadims BARTKEVICS ${ }^{2,3}$, Vytaute STARKUTE ${ }^{1}$, \\ Vita KRUNGLEVICIUTE ${ }^{1}$, Dalia CIZEIKIENE ${ }^{4}$, Daiva ZADEIKE ${ }^{4}$, \\ Grazina JUODEIKIENE ${ }^{4}$, Zita MAKNICKIENE ${ }^{5}$ \\ ${ }^{1}$ Lithuanian University of Health Sciences \\ Tilžès 18, Kaunas, Lithuania \\ ${ }^{2}$ University of Latvia \\ Kr. Valdemara 48, Riga, Latvia \\ ${ }^{3}$ Institute of Food Safety, Animal Health and Environment \\ Lejupes 3, Riga, Latvia \\ ${ }^{4}$ Kaunas University of Technology \\ Radvilènų 19, Kaunas, Lithuania \\ E-mail: dalia.cizeikiene@ktu.lt \\ ${ }^{5}$ Vokè Branch, Lithuanian Research Centre for Agriculture and Forestry \\ Žalioji 2, Traku Voké, Vilnius, Lithuania
}

\begin{abstract}
The aim of the current study was to evaluate the chemical composition, nutritional value, fatty acid composition, macro- ( $\mathrm{Na}, \mathrm{Mg}, \mathrm{K}, \mathrm{Ca}$ ) and microelements, including essential (Cr, Mn, Co, Ni, Fe, Zn, Se and $\mathrm{Cu}$ ) and nonessential ( $\mathrm{Al}, \mathrm{As}, \mathrm{Sr}, \mathrm{Cd}, \mathrm{Pb}$ and $\mathrm{Ag}$ ) elements, in the seeds of the yellow lupine (Lupinus luteus L.) variety 'Vilčiai', the narrow-leaved lupine (L. angustifolius L.) variety 'Vilniai' and the six new hybrid lines (Nos. 1700, 1701, 1703, 1072, 1734 and 1800) bred from the narrow-leaved lupine (L. angustifolius) in Lithuania. Gas chromatography with a flame ionization detector showed that oleic and linoleic unsaturated fatty acids were the dominant fatty acids in lupine seeds, which accounted for on average $33.2 \%$ and $38.4 \%$ of the total fatty acids, respectively.

The highest protein content, measured by the Kjeldahl method, was detected in the 'Vilčiai' lupine seeds (40.8\%) and for the tested hybrid lines it was by $20.1-25.7 \%$ lower. The content of alkaloids in the seeds of lupine varieties 'Vilčiai' and 'Vilniai' was $0.021 \%$ and $0.030 \%$, respectively; while in the new hybrid lines of L. angustifolius the content of alkaloids was less and varied from $0.011 \%$ to $0.012 \%$. Analysis of macro- and microelements of lupine seeds performed using inductively coupled plasma mass spectrometry revealed that the new hybrid lines had the highest content of $\mathrm{Na}$ (from 1.07 to $1.19 \mathrm{mg} \mathrm{g}^{-1}$ dry mass (d.m.), respectively), whereas the highest content of $\mathrm{Mg}$ and $\mathrm{K}$ was found in 'Vilčiai' seeds (3.44 and $13.9 \mathrm{mg} \mathrm{g}^{-1}$ d.m., respectively). Among the L. angustifolius hybrid lines tested, the highest content of $\mathrm{Mg}$ and $\mathrm{K}$ in the seeds was determined for the four hybrid lines Nos. 1701, 1703, 1072 and 1734.

The highest contents of Mn, Fe, Zn and Se were observed in 'Vilčiai' seeds $\left(147.65,73.52,59.84\right.$ and $0.13 \mu \mathrm{g} \mathrm{g}^{-1}$ d.m., respectively). The concentration of nonessential elements in the tested lupine seeds was far below the levels that cause a health risk.
\end{abstract}

Key words: fatty acid, inductively coupled plasma mass spectrometry, lupine, macro- and microelements, nutrition value.

\section{Introduction}

The demand of the ever-growing world population for protein foods is no longer sustainable through animal products alone. To compensate for this deficiency, soya bean has become the prevalent source of plant proteins for food and feed. Europe has become heavily dependent on soya bean imports, entailing trade agreements and quality standards that do not fully satisfy the European citizens' expectations. During the recent years human consumption of lupine seeds has increased worldwide as lupine seeds are a good source of nutrients, 
not only proteins but also lipids, dietary fibre, minerals, and vitamins. There are variations in the protein content between species and cultivars, the growing conditions and soil types (Martínez-Villaluenga et al., 2006). Although lupine belongs to the legumes and is not described as an oilseed crop, it has a considerable amount of oil in its seeds (Uzun et al., 2007).

Lupine seeds are a good source of macroand microelements. Essential elements are classified as macronutrients $(\mathrm{N}, \mathrm{P}, \mathrm{K}, \mathrm{Ca}, \mathrm{Mg}$ and $\mathrm{S})$ and micronutrients ( $\mathrm{Fe}, \mathrm{Cu}, \mathrm{Mn}, \mathrm{Zn}, \mathrm{B}, \mathrm{Mo}, \mathrm{Ni}$ and $\mathrm{Cl}$ ), and the classification is based on the relative abundance in plants. Heavy metals and metalloids represent a series of environmental hazards worldwide (Ehsan et al., 2015). The accumulation of heavy metals in plants is related to the concentration and chemical fractions of the metals in soils (Ehsan et al., 2007). Lupinus species have shown a relatively high tolerance to various environmental stresses, nitrate excess, low root temperature, lime excess and salinity, and therefore could be cultivated worldwide. Some Lupinus species are able to accumulate $\mathrm{Zn}, \mathrm{Cd}, \mathrm{Mg}$ and $\mathrm{Al}, \mathrm{Hg}$ (Esteban et al., 2008), $\mathrm{Pb}$ and $\mathrm{Cr}$ (XimenezEmbun et al., 2001), therefore new species of lupine should be examined before application for food. White lupine (Lupinus albus L.) tolerance to $\mathrm{Cd}$ and $\mathrm{As}$ with few toxic visual symptoms has been reported, as well as its ability for phosphate assisted phytoextraction of As and for phytostabilization of acidified multi-contaminated soils (Vazquez et al., 2006). Ximenez-Embun et al. (2001) reported that L. albus, L. luteus, L. angustifolius and $L$. hispanicuswere are able to grow under extreme conditions (wastewater, $\mathrm{pH}$ lower than 2) and to remove $98 \%$ of the initial amount of toxic metals present in the sample. The presence of quinolizidine alkaloids and some anti-nutritional factors hinders lupine consumption in the form of raw seeds. To make the lupine suitable for human consumption, different modern and traditional processing methods have been developed. Among the methods, soaking after roasting, boiling, germination, fermentation and alkaline treatments can be mentioned (Erbas, 2010).

In Lithuania, the narrow-leaved lupine breeding program was started in 1995 at Vokè Branch of Lithuanian Institute of Agriculture (currently - Lithuanian Research Centre for Agriculture and Forestry). The breeding work is done in three directions: 1) low-alkaloids narrowleaved lupine lines bred for food industry, 2) lowalkaloids narrow-leaved lines bred for animal feed and 3) narrow lupines lines bred for green manure. The seeds of hybrid lines Nos. 1675, 1700, 1702 and 1703 have low content of alkaloids (0.039-0.064\%) (Maknickienè, Ražukas, 2007). Hybrid lines Nos. 1672, 1719 and 1700 were tested as an ingredient for wheat bread, and it was found that addition of up to $10 \%$ of these seeds can improve wheat bread quality (Bartkiene et al., 2013). The chemical composition of lupine seeds is one of the decisive factors for deciding on further use in food or feed industry, therefore the chemical composition of seeds of new hybrid lines should be examined before application in food industry.
The aim of the study was to evaluate the chemical composition, nutritional value, fatty acids composition, macro- and micronutrients in the seeds of the yellow lupine (Lupinus luteus L.) variety 'Vilčiai', the narrow-leaved lupine (L. angustifolius L.) variety 'Vilniai' and the six new hybrid lines (Nos. 1700, 1701, $1703,1072,1734$ and 1800) bred from the narrow-leaved lupine L. angustifolius in Lithuania.

\section{Materials and methods}

Materials. The seeds of lupine (Lupinus L.) varieties 'Vilčiai' and 'Vilniai' and hybrid lines Nos. 1700, 1701, 1703, 1072, 1734 and 1800 bred at the Voke Branch of Lithuanian Research Centre for Agriculture and Forestry (Trakų Voké, Lithuania) were analysed in this study. The research was conducted in 2014-2015.

Evaluation of proximate composition of lupine seeds. Chemical composition of lupine seeds was investigated according to the ICC standard methods. Moisture content was determined by drying the samples at $105 \pm 2{ }^{\circ} \mathrm{C}$ to constant weight (ICC 109/01:1976. Determination of the moisture content of cereals and cereal products). Ash content was determined by calcinations at $900^{\circ} \mathrm{C}$ (ICC 104/1:1990. Determination of ash in cereals and cereal products). Nitrogen content was determined using Kjeldahl method with a factor of 5.7 to determine protein content (ICC 105/2:2001. Determination of crude protein in cereals and cereal products for food and for feed). The total lipid content was determined by extraction in the Soxhlet apparatus ("Boeco", Germany) with hexane technical grade (Fisher Scientific, USA) (ICC 136:1984. Cereals and cereal products - Determination of total fat content). Carbohydrates content in lupine seeds was calculated by the following formula: $100-$ (weight in grams [protein + fat + water + ash] in $100 \mathrm{~g}$ of seeds). Energy value was calculated by multiplying the content of protein, fat and carbohydrates by the appropriate factor $-4,4$ and 9 for protein, carbohydrates and fat, respectively. All the measurements of analysed samples were made in triplicate.

Determination of alkaloids. Determination of alkaloids concentration was carried out as described by Maknickiene et al. (2013).

Analysis of fatty acid composition. Fatty acid composition of lupine seed oil was determined using a gas chromatography-flame ionization detector GC-FID, gas chromatograph Agilent 6890N (Agilent Technologies, USA). Methyl esters of fatty acids were dissolved in anhydrous 99.5\%(Sigma-Aldrich, Germany)cyclohexane $(100 \mathrm{mg}$ in $4 \mathrm{~mL})$ and were prepared by transmethylation

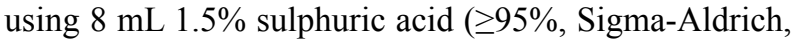
Germany) in the pure (99.9\%) methanol (Sigma-Aldrich, Germany), and kept at $60^{\circ} \mathrm{C}$ for $12 \mathrm{~h}$ in the dark. Samples were cooled, shaken for $30 \mathrm{~s}$ and centrifuged for $10 \mathrm{~min}$, at 3000 relative centrifugal force at $17^{\circ} \mathrm{C}$ and injected (100 $\mu \mathrm{L}$ of the upper part of supernatant, diluted before in cyclohexane $1: 9$, respectively) into a capillary BPX90 column $(60 \mathrm{~m} \times 0.32 \mathrm{~mm}, \mathrm{ID} \times 0.25 \mu \mathrm{m}$ film thickness $)$ (SGE, USA). The following conditions were used: flame 
ionization detector $-280^{\circ} \mathrm{C}, \mathrm{H}_{2}$ flow $-40 \mathrm{ml} \mathrm{min}{ }^{-1}$, air flow $-450 \mathrm{ml} \mathrm{min}^{-1}$, helium (carrier gas) flow $-1 \mathrm{ml} \mathrm{min}^{-1}$, injector $-250^{\circ} \mathrm{C}$ (split $1: 10$ ), oven temperature $-50^{\circ} \mathrm{C}$ (2 min), $4^{\circ} \mathrm{C} \min ^{-1}$ to $245^{\circ} \mathrm{C}$ and $245^{\circ} \mathrm{C}$ for $15 \mathrm{~min}$. The identification of fatty acid was carried out by retention times and expressed as percentage of the total peak area of all the fatty acids in the oil sample.

Analysis of macro- and microelements of lupine seeds using inductively coupled plasma mass spectrometry (ICP-MS). The seeds were milled and homogenised (final particle size $\leq 150 \mu \mathrm{m})$. For the analysis the following chemicals were used: nitric acid (concentration $\geq 69.0 \%$ ), for-trace element analysis (Sigma-Aldrich, France), hydrogen peroxide, $30 \% \mathrm{w} / \mathrm{w}$ (weight/weight), extra pure (Scharlau, Spain), multielement standard solution V for ICP-MS calibration (Sigma-Aldrich, France). Agilent 7700x ICP-MS (Agilent Technologies, Japan), software Mass Hunter Work Station for ICP-MS, version B.01.01 (Agilent Technologies, Japan) were used for analysis. For sample preparation for ICP-MS analysis, $0.3 \mathrm{~g}$ of milled lupine seeds was accurately weighed in a microwave vessel. $2 \mathrm{~mL}$ of de-ionized water, $8 \mathrm{~mL}$ of concentrated nitric acid and $2 \mathrm{~mL}$ of concentrated hydrogen peroxide were added and waited for $2-8 \mathrm{~h}$ for reaction stabilization until the formation of bubbles had finished. The vessel was sealed and heated in the microwave system. The following thermal conditions were applied: $150^{\circ} \mathrm{C}$ temperature was reached in approx. $20 \mathrm{~min}$ and remained such for $30 \mathrm{~min}$, and then $200^{\circ} \mathrm{C}$ was reached in approx. $20 \mathrm{~min}$ and remained such for $30 \mathrm{~min}$ for the completion of specific reactions. After cooling (approx. $40 \mathrm{~min}$ ) the prepared solution was filtered through the filter with a pore size of $8-10 \mu \mathrm{m}$. The solution was transferred to a $50 \mathrm{~mL}$ volumetric flask and filled with water to 50 $\mathrm{mL}$ volume. The following operating conditions of Agilent 7700x ICP-MS were used for the analysis of the samples: plasma mode - normal, robust; RF forward power $1300 \mathrm{~W}$; sampling depth $8.00 \mathrm{~mm}$; carrier gas flow $0.6 \mathrm{~L} \mathrm{~min}{ }^{-1}$; dilution gas flow $0.4 \mathrm{~L} \mathrm{~min}^{-1}$; spray chamber temperature $2^{\circ} \mathrm{C}$; extraction lens $1 \mathrm{~V}$; kinetic energy discrimination $3 \mathrm{~V}$.

Statistical analysis. In order to evaluate the influence of variety and hybrid line on the chemical composition of lupine seeds, the data were subjected to one-way analysis of variance (ANOVA), statistical program SPSS, version 11.0 (SPSS Inc., USA). Differences between groups were considered significant at $p<0.05$.

\section{Results and discussion}

Proximate composition and energy value of analysed lupine seeds. Proximate composition of lupine seeds is presented in Table 1. The highest protein content was found in the Lupinus luteus, variety 'Vilčiai' (40.8\%), while in L. angustifolius seeds protein content was lower (from $20.1 \%$ to $25.7 \%$ ). Similar results of protein content were reported by Porres et al. (2007). The least content of proteins was observed for hybrid lines Nos. 1700 and 1800 (30.3 $\pm 0.11 \%$ and $30.3 \pm 0.13 \%$, respectively). According to literature, there is considerable variation of protein content among lupine species (from $24 \%$ to $61 \%$ ), for example yellow lupine seeds contain $39-47 \%$ and blue lupine $31-38 \%$ of proteins. Moreover, there are variations in the protein content between species and cultivars, growing conditions and soil types (MartínezVillaluenga et al., 2006). According to literature, lupine seed protein has a relatively good amino acid profile with high content of arginine (4.1-11.2\%), leucine (7.59.4\%), lysine (4.3-5.2\%) and phenylalanine (3.0-6.8\%). Among pulses, lupine ranked third in protein quality after soybean and chickpea (Nwokolo, Smartt, 1996.).

Table 1. Composition (\%) of lupine seeds (dry mass)

\begin{tabular}{lcccccc}
\hline \multicolumn{1}{c}{$\begin{array}{c}\text { Lupine varieties and } \\
\text { hybrid lines }\end{array}$} & Proteins & Fat & Carbohydrates & Moisture & Ash & Alkaloids \\
\hline $\begin{array}{l}\text { L. luteus 'Vilčiai' } \\
\text { L. angustifolius 'Vilniai' }\end{array}$ & $40.8 \pm 0.1 \mathrm{c}$ & $4.4 \pm 0.1 \mathrm{a}$ & $41.6 \pm 0.1 \mathrm{a}$ & $9.0 \pm 0.1 \mathrm{a}$ & $4.3 \pm 0.2 \mathrm{c}$ & $0.021 \pm 0.005 \mathrm{c}$ \\
L. angustifolius hybrid lines & & & & & & \\
No. 1701 & $31.0 \pm 0.1 \mathrm{a}$ & $5.2 \pm 0.1 \mathrm{~b}$ & $50.2 \pm 0.2 \mathrm{bc}$ & $10.4 \pm 0.1 \mathrm{bc}$ & $3.2 \pm 0.2 \mathrm{~b}$ & $0.012 \pm 0.002 \mathrm{~b}$ \\
No. 1072 & $31.9 \pm 0.7 \mathrm{ab}$ & $5.8 \pm 0.1 \mathrm{c}$ & $47.4 \pm 0.2 \mathrm{~b}$ & $11.8 \pm 0.1 \mathrm{e}$ & $3.2 \pm 0.1 \mathrm{ab}$ & $0.012 \pm 0.002 \mathrm{~b}$ \\
No. 1700 & $30.3 \pm 0.1 \mathrm{a}$ & $6.4 \pm 0.1 \mathrm{~d}$ & $49.2 \pm 0.1 \mathrm{~b}$ & $11.1 \pm 0.2 \mathrm{~d}$ & $3.0 \pm 0.2 \mathrm{a}$ & $0.011 \pm 0.002 \mathrm{a}$ \\
No. 1703 & $32.0 \pm 0.1 \mathrm{ab}$ & $7.0 \pm 0.1 \mathrm{de}$ & $46.9 \pm 0.2 \mathrm{~b}$ & $11.1 \pm 0.2 \mathrm{~d}$ & $2.9 \pm 0.2 \mathrm{a}$ & $0.012 \pm 0.002 \mathrm{~b}$ \\
No. 1734 & $32.6 \pm 0.1 \mathrm{~b}$ & $6.7 \pm 0.1 \mathrm{~d}$ & $47.7 \pm 0.2 \mathrm{~b}$ & $9.9 \pm 0.2 \mathrm{~b}$ & $3.1 \pm 0.1 \mathrm{ab}$ & $0.011 \pm 0.002 \mathrm{a}$ \\
No. 1800 & $30.3 \pm 0.1 \mathrm{a}$ & $5.6 \pm 0.2 \mathrm{c}$ & $50.8 \pm 0.3 \mathrm{bc}$ & $10.4 \pm 0.1 \mathrm{bc}$ & $2.9 \pm 0.1 \mathrm{a}$ & $0.012 \pm 0.002 \mathrm{~b}$ \\
\hline
\end{tabular}

Notes. Data expressed as means $(\mathrm{n}=5) \pm \mathrm{SD}$ (standard deviation). Values within each group in the same superscript letter are not different at $P \leq 0.05$.

Alkaloid content in the seeds of L. angustifolius hybrid lines was in range $0.011-0.012 \%$, whereas in the seeds of L. luteus variety 'Vilčiai' and L. angustifolius variety 'Vilniai' the contents of alkaloids were $0.021 \%$ and $0.030 \%$, respectively. Higher contents of alkaloids were reported by Maknickiene et al. (2013) in L. luteus variety 'Trakiai' $(0.022 \%)$ and L. angustifolius line No. $1702(0.085 \%)$.
Higher carbohydrate content was observed in L. luteus variety 'Vilčiai' $(41.6 \%$ ) compared with L. angustifolius variety 'Vilniai' (49.3\%), whereas in two hybrid lines (Nos. 1701 and 1800) bred from L. angustifolius the content of carbohydrates was higher (50.2\% and $50.8 \%$, respectively).

The highest content of mineral elements was found in 'Vilčiai' seeds $(4.25 \%)$, whereas the lowest 
content was observed in the seed of line No. 1800 $(2.93 \%)$. The lowest fat content was found in 'Vilčiai' seeds $(4.4 \%)$, while the highest fat content was in the hybrid lines Nos. 1700, 1703 and 1734 (6.4, 7.0 and $6.7 \%$, respectively). According to Hudson (1979), L. mutabilis Sweet seeds are one of the richest in fats (13$23 \%$ ), whereas the content of fat in other species such as L. albus (5-14\%), L. luteus (5-7\%) and L. angustofilius (4-8.5\%) was found to be lower. In general, the content of fat in lupine is relatively high and only a few pulses like soybean exceed lupine in this respect. According to Uzun et al. (2007), the content of fat in lupine is ranked third after ground nut (Arachis hypogeae L.) and soybean (Glycin max L. Merril) among the legumes. The high fat content confers a high energy value on lupine meal as food and feed. As dietary oil, lupine compares favourably with soybean and rape seed oils.

Energy value of L. luteus variety 'Vilčiai' and L. angustifolius variety 'Vilniai' was 369 and $378 \mathrm{kcal}$ $100 \mathrm{~g}^{-1}$ seeds, respectively, whereas in L. angustifolius hybrid lines energy value ranged in 369-382 kcal $100 \mathrm{~g}^{-1}$ seeds. The highest energy value of seeds was observed in L. angustifolius hybrid line (No. 1734) - $382 \mathrm{kcal}^{100 \mathrm{~g}^{-1}}$ seeds.

Results of ANOVA test indicated that the contents of proteins $(\mathrm{F}(483.139)=244.136, p=0.0001)$, fat $(\mathrm{F}(138.794)=14.816, p<0.0001)$, carbohydrates
$(\mathrm{F}(686.995)=174.986, p<0.0001)$, minerals $(\mathrm{F}(23.574)$ $=3.956, p<0.0001)$ and alkaloids $(\mathrm{F}(148.527)=0.001$, $p<0.0001)$ in lupine seeds significantly depended on the hybrid line.

Fatty acid composition of lupine seeds. Fatty acid composition of lupine seeds is presented in Table 2 . We found that the main fatty acids in hybrid lines bred in Lithuania are unsaturated fatty acids - oleic acid (C18:1) and linoleic acid(C18:2), which accounted for respectively $33.2 \pm 3.9 \%$ and $38.4 \pm 4.5 \%$ of the total content of fatty acids, whereas the concentrations of saturated fatty acids were lower. Monounsaturated fatty acids - paullinic acid (C20:1) and 10-pentadecenoic acid methyl ester (C20:1) were found only in the L. luteus variety 'Vilčiai', 1.3 $\pm 0.09 \%$ and $0.4 \pm 0.05 \%$, respectively. Palmitic acid (C16:0) content in lupine seeds was on average $10.8 \pm$ $2.7 \%$ of the total fatty acid content, whereas the content of other saturated fatty acids was found significantly less. Similar results were reported by Uzun et al. (2007) as they found that among the unsaturated fatty acids from L. albus seed oleic and linolenic acids were dominant. High content of unsaturated fatty acids indicates that lupine can be a potential source of considerable amount of useful fats. Moreover, the high content of linoleic and oleic fatty acids make lupine seed a good source of essential fatty acids.

Table 2. Fatty acid composition (\% of total fatty acids) of lupine seeds

\begin{tabular}{|c|c|c|c|c|c|c|c|c|}
\hline $\begin{array}{c}\text { Lupine varieties and } \\
\text { hybrid lines }\end{array}$ & $\mathrm{C} 16: 0$ & $\mathrm{C} 18: 0$ & $\mathrm{C} 18: 1$ & C18:2 & $\mathrm{C} 20: 0$ & $\mathrm{C} 18: 3$ & $\mathrm{C} 22: 0$ & $\begin{array}{l}\text { C24:0+ } \\
\text { C20:5 }\end{array}$ \\
\hline L. luteus 'Vilčiai' & $4.2 \pm 0.1 \mathrm{a}$ & $2.4 \pm 0.3 \mathrm{a}$ & $25.2 \pm 0.2 \mathrm{a}$ & $48.0 \pm 0.3 \mathrm{~d}$ & $2.9 \pm 0.2 \mathrm{f}$ & $7.9 \pm 0.2 \mathrm{e}$ & $6.9 \pm 0.3 \mathrm{e}$ & $0.8 \pm 0.1 \mathrm{c}$ \\
\hline $\begin{array}{l}\text { L. angustifolius } \\
\text { 'Vilniai' } \\
\text { L. angustifolius hybri }\end{array}$ & $\begin{array}{l}11.4 \pm 0.1 \mathrm{c} \\
\mathrm{d} \text { lines }\end{array}$ & $6.5 \pm 0.1 b$ & $30.8 \pm 0.2 b$ & $41.7 \pm 0.3 \mathrm{c}$ & $0.9 \pm 0.1 \mathrm{a}$ & $6.1 \pm 0.1 \mathrm{c}$ & $2.1 \pm 0.2 \mathrm{~b}$ & $0.5 \pm 0.1 \mathrm{~b}$ \\
\hline No. 1701 & $11.6 \pm 0.1 \mathrm{c}$ & $8.0 \pm 0.2 \mathrm{~d}$ & $32.6 \pm 0.1 \mathrm{c}$ & $37.5 \pm 0.2 \mathrm{~b}$ & $1.2 \pm 0.1 \mathrm{~d}$ & $6.4 \pm 0.2 \mathrm{~cd}$ & $2.3 \pm 0.1 \mathrm{c}$ & $0.4 \pm 0 \mathrm{a}$ \\
\hline No. 1072 & $12.0 \pm 0.1 \mathrm{~cd}$ & $8.2 \pm 0.2 \mathrm{~d}$ & $33.4 \pm 0.2 \mathrm{c}$ & $37.3 \pm 0.2 \mathrm{~b}$ & $1.0 \pm 0.1 \mathrm{~b}$ & $5.5 \pm 0.2 b$ & $2.1 \pm 0.1 \mathrm{~b}$ & $0.5 \pm 0 \mathrm{~b}$ \\
\hline No. 1700 & $11.7 \pm 0.2 \mathrm{c}$ & $9.1 \pm 0.2 \mathrm{e}$ & $36.0 \pm 0.1 \mathrm{~d}$ & $34.4 \pm 0.3 \mathrm{a}$ & $1.1 \pm 0.03 \mathrm{c}$ & $5.1 \pm 0.1 \mathrm{a}$ & $2.1 \pm 0.1 \mathrm{~b}$ & $0.5 \pm 0 \mathrm{~b}$ \\
\hline No. 1703 & $12.0 \pm 0.2 \mathrm{~cd}$ & $7.5 \pm 0.2 \mathrm{c}$ & $34.0 \pm 0.1 \mathrm{c}$ & $38.3 \pm 0.2 b$ & $1.0 \pm 0 \mathrm{~b}$ & $4.9 \pm 0.1 \mathrm{a}$ & $1.8 \pm 0.2 \mathrm{a}$ & $0.5 \pm 0 \mathrm{~b}$ \\
\hline No. 1734 & $11.5 \pm 0.2 \mathrm{c}$ & $8.2 \pm 0.2 \mathrm{~d}$ & $36.2 \pm 0.2 \mathrm{~d}$ & $35.2 \pm 0.2 \mathrm{a}$ & & $5.3 \pm 0.1 \mathrm{~b}$ & $2.0 \pm 0.3 \mathrm{~b}$ & $0.5 \pm 0 \mathrm{~b}$ \\
\hline No. 1800 & $11.6 \pm 0.3 \mathrm{c}$ & $7.4 \pm 0.3 \mathrm{c}$ & $37.2 \pm 0.2 \mathrm{~d}$ & $34.8 \pm 0.2 \mathrm{a}$ & $1.0 \pm 0 \mathrm{~b}$ & $5.4 \pm 0.1 \mathrm{~b}$ & $2.1 \pm 0.3 \mathrm{~b}$ & $0.5 \pm 0 \mathrm{~b}$ \\
\hline Average & $10.8 \pm 2.7 \mathrm{~b}$ & $7.2 \pm 2.1 \mathrm{c}$ & $33.2 \pm 3.9 \mathrm{c}$ & $38.4 \pm 4.5 \mathrm{~b}$ & $1.3 \pm 0.7 \mathrm{e}$ & $5.8 \pm 1.0 \mathrm{c}$ & $2.7 \pm 1.7 \mathrm{~d}$ & $0.5 \pm 0.1 \mathrm{~b}$ \\
\hline
\end{tabular}

Notes. Data expressed as means $(\mathrm{n}=5) \pm \mathrm{SD}$ (standard deviation). C16:0 - palmitic acid, C18:0 - stearic acid, C18:1 - oleic acid, C18:2 - linoleic acid, C20:0 - arachidic acid, C18:3 - $\alpha$-linolenic acid, C22:0 - behenic acid, C24:0+C20:5 - lignoceric acid + eicosapentaenoic acid, C15:1 - ginkgolic acid, C20:1 - eicosenoic acid. Values within each group in the same superscript letter are not different at $P \leq 0.05$.

Results of ANOVA test indicated a significant influence of variety and hybrid line on palmitic acid $(\mathrm{C} 16: 0)(\mathrm{F}(854.266)=148.201, p=0.0001)$, stearic acid $(\mathrm{C} 18: 0)(\mathrm{F}(260.178)=89.696, p<0.0001)$, oleic acid $(\mathrm{C} 18: 1)(\mathrm{F}(1450.286)=310.905, p<0.0001)$, linoleic acid $(\mathrm{C} 18: 2)(\mathrm{F}(1064.961)=432.840, p<0.0001)$, arachidic $\operatorname{acid}(\mathrm{C} 20: 0)(\mathrm{F}(157.827)=9.225, p<0.0001), \alpha$-linolenic acid $(\mathrm{C} 18: 3)(\mathrm{F}(128.186)=19.785, p<0.0001)$, behenic acid $(\mathrm{C} 22: 0)(\mathrm{F}(203.897)=61.605, p<0.0001)$, and lignoceric acid + eicosapentaenoic acid (C24:0+C20:5) $(\mathrm{F}(17.512)=0.285, p<0.0001) \%$ of total fatty acid in lupine seeds.

Macro- and microelements of lupine seeds. Macroelements such as $\mathrm{Na}, \mathrm{Mg}, \mathrm{K}$ and $\mathrm{Ca}$ are essential for a wide variety of metabolic and physiological processes in the human body; therefore should be included in daily diets to prevent chronic diseases (Williams, 2006; Alsafwah et al., 2007). The content of macroelements in lupine seeds depended on lupine variety and hybrid line (Table 3). The highest content of $\mathrm{Na}$ was observed in hybrid lines Nos. 1700, 1701, 1703, 1072, 1734 and 1800 (from $1.07 \pm 0.04$ to $1.19 \pm 0.04 \mathrm{mg} \mathrm{g}^{-1}$ ). While $\mathrm{Na}$ is an essential nutrient, dietary intakes in Europe today far exceed nutritional requirements. Mean daily $\mathrm{Na}$ intakes of populations in Europe range from about 3-5 g and are well in excess of dietary needs (about $1.5 \mathrm{~g}$ per day in adults, according to Dietary reference intakes... (DRI, 2005). The content of $\mathrm{Na}$ in lupine seeds did not 
exceed the recommended level; therefore the tested lupines are not harmful for human health. The highest content of $\mathrm{Mg}$ and $\mathrm{K}$ was observed in 'Vilčiai' seeds, $3.44 \pm 0.09$ and $13.9 \pm 0.12 \mathrm{mg} \mathrm{g}^{-1} \mathrm{~d}$.m., respectively. The content of $\mathrm{Mg}$ ranged from 2.00 (in the seeds of 'Vilniai') to $3.44 \mathrm{mg} \mathrm{g}^{-1} \mathrm{~d}$.m. (in the seeds of 'Vilčiai'). The lowest content of $\mathrm{K}$ and $\mathrm{Ca}$ was found in the seeds of 'Vilniai' -12.6 and $1.46 \mathrm{mg} \mathrm{g}^{-1}$ d.m., respectively. The content of $\mathrm{Ca}$ and $\mathrm{Na}$ was the highest in the hybrid lines Nos. 1700, 1701, 1703, 1072, 1734 and 1800 - varied in range 1.65-2.41 and 1.01-1.19 $\mathrm{mg} \mathrm{g}^{-1}$ d.m., respectively. Among the lines of $L$. angustifolius, the highest content of $\mathrm{Mg}$ and $\mathrm{K}$ was determined in the seeds of hybrid line No. 1700 (2.48 and $13.61 \mathrm{~g} \mathrm{~kg}^{-1}$ d.m., respectively). Porres et al. (2007) reported similar $\mathrm{Mg}$ and $\mathrm{K}$ values in L. angustifolius seeds. Dietary reference intakes... (DRI, 2005) recommendations for adults (31-50 years old) are 420, 4700 and $100 \mathrm{mg}$ per day of $\mathrm{Mg}, \mathrm{K}$ and $\mathrm{Ca}$, respectively. The lowest coefficient of variation in lupine seeds was found for K (3.61\%).

Table 3. Macroelements ( $\mathrm{mg} \mathrm{g}^{-1}$ dry mass) in lupine seeds

\begin{tabular}{|c|c|c|c|c|}
\hline $\begin{array}{c}\text { Lupine varieties and } \\
\text { hybrid lines }\end{array}$ & $\mathrm{Na}$ & $\mathrm{Mg}$ & $\mathrm{K}$ & $\mathrm{Ca}$ \\
\hline L. luteus 'Vilčiai' & $0.93 \pm 0.06 \mathrm{a}$ & $3.44 \pm 0.09 \mathrm{e}$ & $13.91 \pm 0.12 b$ & $1.93 \pm 0.25 \mathrm{c}$ \\
\hline L. angustifolius 'Vilniai' & $1.01 \pm 0.09 \mathrm{~b}$ & $2.00 \pm 0.11 \mathrm{a}$ & $12.63 \pm 0.09 \mathrm{a}$ & $1.46 \pm 0.14 \mathrm{a}$ \\
\hline \multicolumn{5}{|l|}{ L. angustifolius hybrid lines } \\
\hline No. 1701 & $1.07 \pm 0.04 \mathrm{c}$ & $2.45 \pm 0.14 \mathrm{~d}$ & $12.72 \pm 0.21 \mathrm{a}$ & $2.23 \pm 0.09 \mathrm{~d}$ \\
\hline No. 1072 & $1.11 \pm 0.07 \mathrm{c}$ & $2.33 \pm 0.15 \mathrm{c}$ & $12.91 \pm 0.15 \mathrm{a}$ & $2.53 \pm 0.15 \mathrm{f}$ \\
\hline No. 1700 & $1.12 \pm 0.04 \mathrm{c}$ & $2.48 \pm 0.12 \mathrm{~d}$ & $13.61 \pm 0.17 b$ & $1.92 \pm 0.12 \mathrm{c}$ \\
\hline No. 1703 & $1.18 \pm 0.02 \mathrm{~d}$ & $2.14 \pm 0.21 b$ & $13.40 \pm 0.23 b$ & $1.65 \pm 0.20 b$ \\
\hline No. 1734 & $1.18 \pm 0.09 \mathrm{~d}$ & $2.29 \pm 0.23 \mathrm{c}$ & $13.49 \pm 0.20 \mathrm{~b}$ & $2.41 \pm 0.08 \mathrm{e}$ \\
\hline No. 1800 & $1.19 \pm 0.04 \mathrm{~d}$ & $2.44 \pm 0.17 \mathrm{~cd}$ & $13.30 \pm 0.19 \mathrm{ab}$ & $2.04 \pm 0.06 \mathrm{c}$ \\
\hline \multicolumn{5}{|c|}{ Statistical analysis } \\
\hline Mean & 1.10 & 2.45 & 13.23 & 2.02 \\
\hline Standard deviation (SD) & 0.09 & 0.43 & 0.48 & 0.36 \\
\hline$P$ value (two tailed) & \multicolumn{4}{|c|}{$<0.0001$} \\
\hline Coefficient of variation $\%$ & 8.38 & 17.75 & 3.61 & 17.99 \\
\hline
\end{tabular}

Note. Data expressed as means $(\mathrm{n}=5) \pm \mathrm{SD}$; significant, when $P \leq 0.05$. Values within each group in the same superscript letter are not different at $P \leq 0.05$.

Krejpcio et al. (2006) analysed L. angustifolius variety 'Baron' and observed similar content of $\mathrm{Ca}$ (2.71 $\mathrm{mg} \mathrm{g}^{-1} \mathrm{~d} . \mathrm{m}$.), whereas the content of $\mathrm{Mg}\left(1.74 \mathrm{mg} \mathrm{g}^{-1}\right.$ d.m.) was determined significantly lower in this variety compared with Lithuanian varieties of L. angustifolius. Moreover, $\mathrm{Ca}$ content was observed higher in the seeds of L. angustifolius variety 'Vilniai' and hybrid lines in comparison with L. angustifolius var. troll and L. angustifolius var. emir. Results of $A N O V A$ test indicated that there is a significant influence of variety and hybrid line on $\mathrm{Na}(\mathrm{F}(6.798)=0.178, p=0.001), \mathrm{Mg}(\mathrm{F}(22.331)$ $=3.959, p<0.0001), \mathrm{K}(\mathrm{F}(20.526)=4.436, p<0.0001)$ and $\mathrm{Ca}(\mathrm{F}(17.913)=2.776, p<0.0001)$ content in seeds. The contents of $\mathrm{Zn}$ and Fe reported in L. angustifolius variety 'Baron' were similar to those in the hybrid lines.

The content of $\mathrm{Zn}$ and $\mathrm{Fe}$ in the seeds of the L. luteus L. variety 'Vilčiai' was observed significantly higher (59.84 and $73.52 \mu \mathrm{g} \mathrm{g}^{-1}$ d.m., respectively), but did not exceed the dietary recommendations (DRI, 2005). As a result, the tested lupine seeds could be recommended in human diet as a source of essential elements such as $\mathrm{Zn}$ and Fe. Essential and non-essential microelements in lupine seeds are presented in Table 4.

In humans and animals, $\mathrm{Cr}$ is an essential nutrient that plays a significant role in a metabolism of glucose, fat and protein through potentiation of insulin action. There is limited data on which to base tolerable daily intakes for chromium. The highest concentration of chromium was observed in the seeds of hybrid line No. 1703 (1.81 $\mu \mathrm{g} \mathrm{g}^{-1} \mathrm{~d} . \mathrm{m}$.), whereas the lowest concentration was in the seeds of 'Vilčiai' variety $\left(0.73 \mu \mathrm{g} \mathrm{g}^{-1} \mathrm{~d}\right.$.m. $)$.

The content of $\mathrm{Mn}$ in lupine seeds strongly depended on the field conditions and the species. Hung et al. (1987) examined 33 samples of seeds from two species of lupin and found that $L$. angustifolius had a much lower Mn content $\left(61 \mu \mathrm{g} \mathrm{g}^{-1}\right.$ d.m.) than L. albus (1316 $\mu \mathrm{g} \mathrm{g}^{-1}$ d.m.). The content of $\mathrm{Mn}$ in the tested Lithuanian lupine seeds varied from 28.1 (hybrid line No. 1701) to 147.7 (variety 'Vilčiai') $\mu \mathrm{g} \mathrm{g}^{-1} \mathrm{~d}$.m.

The highest $\mathrm{Fe}$ and $\mathrm{Zn}$ concentrations (73.52 and $59.84 \mu \mathrm{g} \mathrm{g}^{-1}$ d.m., respectively) were found in the seeds of lupine variety 'Vilčiai'. The concentration of $\mathrm{Ni}$ in the investigated lupine seeds ranged from 1.25 (hybrid line No. 1701) to 2.31 (hybrid line No. 1703) $\mu \mathrm{g} \mathrm{g}^{-1} \mathrm{~d} . \mathrm{m}$. Shah et al. (2011) found that deficiency of $\mathrm{Ni}$ can lead to anaemia as $\mathrm{Ni}$ is considered synergistic to Fe by promoting its intestinal absorption. The highest concentration of $\mathrm{Ni}$ was found in the two lines Nos. 1703 and 1734. Deficiencies of only four elements cobalt as vitamin B12, I, Fe and $\mathrm{Zn}$ - occur with known sufficient frequency in humans so as to be of concern to health professionals (Trace elements..., 1996). The concentration of $\mathrm{Co}$ in lupine seeds ranged from 0.06 (hybrid line No. 1800) to 0.18 (hybrid line No. 1703) $\mu \mathrm{g} \mathrm{g}^{-1}$ d.m.

Se is an essential trace element and integral part of many antioxidant enzymes such as glutathioneperoxidase and selenoprotein P in humans and animals, therefore the deficiency of Se leads to various clinical consequences including cancer, cardiovascular diseases, type 2 diabetes and lung disorders (Kumar, Priyadarsini, 2014). The highest content of Se was found in the seeds of hybrid line No. 1703 and 'Vilčiai' (0.16 and $0.13 \mu \mathrm{g} \mathrm{g} \mathrm{g}^{-1}$ d.m., respectively). Certain elements are essential for human health but if present in excessive concentrations they become toxic (Zelalem, Chandravanshi, 2014). The 
Table 4. Microelements ( $\mu \mathrm{g} \mathrm{g}^{-1}$ dry mass) in lupine seeds

\begin{tabular}{|c|c|c|c|c|c|c|c|c|c|c|c|c|c|c|}
\hline \multirow{2}{*}{$\begin{array}{l}\text { Lupine varieties } \\
\text { and hybrid lines }\end{array}$} & \multicolumn{8}{|c|}{ Essential microelements } & \multicolumn{6}{|c|}{ Non-essential microelements } \\
\hline & $\mathrm{Mn}$ & $\mathrm{Fe}$ & $\mathrm{Zn}$ & $\mathrm{Cu}$ & $\mathrm{Ni}$ & $\mathrm{Cr}$ & $\mathrm{Se}$ & Co & $\mathrm{Sr}$ & $\mathrm{Al}$ & $\mathrm{Pb}$ & $\mathrm{Cd}$ & As & $\mathrm{Ag}$ \\
\hline $\begin{array}{l}\text { L. luteus L. } \\
\text { 'Vilčiai' }\end{array}$ & $\begin{array}{c}147.65 \\
\pm \\
0.30 \mathrm{e}\end{array}$ & $\begin{array}{c}73.52 \\
\pm \\
\pm \\
0.24 \mathrm{~d}\end{array}$ & $\begin{array}{c}59.84 \\
\pm \\
0.08 \mathrm{e}\end{array}$ & $\begin{array}{c}8.07 \\
\pm \\
0.11 \mathrm{e}\end{array}$ & $\begin{array}{c}1.80 \\
\pm \\
0.11 \mathrm{e}\end{array}$ & $\begin{array}{c}0.73 \\
\pm \\
0.09 \mathrm{a} \\
\end{array}$ & $\begin{array}{c}0.13 \\
\pm \\
0.02 \mathrm{c}\end{array}$ & $\begin{array}{c}0.14 \\
\pm \\
0.02 \mathrm{e}\end{array}$ & $\begin{array}{c}16.60 \\
\pm \\
0.21 \mathrm{e}\end{array}$ & $\begin{array}{c}1.19 \\
\pm \\
0.07 \mathrm{~b}\end{array}$ & $\begin{array}{c}0.07 \\
\pm \\
0.01 \mathrm{~b}\end{array}$ & $\begin{array}{c}0.04 \\
\pm \\
0.01 \mathrm{~b}\end{array}$ & $\begin{array}{c}0.03 \\
\pm \\
0.01 \mathrm{~b}\end{array}$ & $<0.005$ \\
\hline $\begin{array}{l}\text { angustifolius } \\
\text { 'Vilniai' }\end{array}$ & $\begin{array}{c}88.16 \\
\pm \\
0.15 \mathrm{c}\end{array}$ & $\begin{array}{c}53.06 \\
\pm \\
0.15 \mathrm{a}\end{array}$ & $\begin{array}{c}36.90 \\
\pm \\
0.23 \mathrm{a}\end{array}$ & $\begin{array}{c}5.53 \\
\pm \\
0.18 \mathrm{~b}\end{array}$ & $\begin{array}{c}1.61 \\
\pm \\
0.13 \mathrm{~d}\end{array}$ & $\begin{array}{c}1.19 \\
\pm \\
0.07 \mathrm{c}\end{array}$ & $\begin{array}{c}0.09 \\
\pm \\
0.01 \mathrm{a}\end{array}$ & $\begin{array}{c}0.12 \\
\quad \pm \\
0.03 \mathrm{~d}\end{array}$ & $\begin{array}{c}11.26 \\
\pm \\
0.15 \mathrm{~b}\end{array}$ & $\begin{array}{c}1.73 \\
\pm \\
0.12 \mathrm{c}\end{array}$ & $\begin{array}{c}0.06 \\
\pm \\
0.02 \mathrm{a}\end{array}$ & $\begin{array}{c}0.04 \\
\pm \\
0.01 \mathrm{~b}\end{array}$ & $\begin{array}{c}0.03 \\
\pm \\
0.03 \mathrm{~b}\end{array}$ & $<0.005$ \\
\hline $\begin{array}{l}\text { L. angustifolius } \\
\text { L. No. } 1701\end{array}$ & $\begin{array}{c}28.13 \\
\pm \\
0.19 \mathrm{a}\end{array}$ & $\begin{array}{c}52.54 \\
\pm \\
0.21 \mathrm{a}\end{array}$ & $\begin{array}{c}35.15 \\
\pm \\
0.17 \mathrm{a}\end{array}$ & $\begin{array}{c}5.10 \\
\pm \\
0.17 \mathrm{a}\end{array}$ & $\begin{array}{c}1.25 \\
\pm \\
0.09 \mathrm{a}\end{array}$ & $\begin{array}{c}1.38 \\
\pm \\
0.11 \mathrm{~d}\end{array}$ & $\begin{array}{c}0.10 \\
\pm \\
0.01 \mathrm{~b}\end{array}$ & $\begin{array}{c}0.03 \\
\pm \\
0.01 \mathrm{a}\end{array}$ & $\begin{array}{c}9.09 \\
\pm \\
0.13 \mathrm{a}\end{array}$ & $\begin{array}{c}0.94 \\
\pm \\
0.06 \mathrm{a}\end{array}$ & $\begin{array}{c}0.06 \\
\pm \\
0.02 \mathrm{a}\end{array}$ & $\begin{array}{c}0.03 \\
\pm \\
0.01 \mathrm{a}\end{array}$ & $\begin{array}{c}0.02 \\
\pm \\
0.01 \mathrm{a}\end{array}$ & $<0.005$ \\
\hline $\begin{array}{l}\text { L. angustifolius } \\
\text { L. No. } 1072\end{array}$ & $\begin{array}{c}122.82 \\
\pm \\
0.36 \mathrm{~d}\end{array}$ & $\begin{array}{c}63.97 \\
\pm \\
0.19 \mathrm{c}\end{array}$ & $\begin{array}{c}53.66 \\
\pm \\
0.11 \mathrm{~d}\end{array}$ & $\begin{array}{c}6.15 \\
\pm \\
0.09 \mathrm{c}\end{array}$ & $\begin{array}{c}1.51 \\
\pm \\
0.10 \mathrm{bc}\end{array}$ & $\begin{array}{c}1.40 \\
\pm \\
0.10 \mathrm{~d}\end{array}$ & $\begin{array}{c}0.10 \\
\pm \\
0.02 \mathrm{~b}\end{array}$ & $\begin{array}{c}0.09 \\
\pm \\
0.02 \mathrm{c}\end{array}$ & $\begin{array}{c}26.10 \\
\pm \\
0.09 \mathrm{~g}\end{array}$ & $\begin{array}{c}6.00 \\
\pm \\
0.23 \mathrm{f}\end{array}$ & $\begin{array}{c}0.11 \\
\pm \\
0.02 \mathrm{~d}\end{array}$ & $\begin{array}{c}0.03 \\
\pm \\
0.01 \mathrm{a}\end{array}$ & $\begin{array}{c}0.02 \\
\pm \\
0.02 \mathrm{a}\end{array}$ & $<0.005$ \\
\hline $\begin{array}{l}\text { L. angustifolius } \\
\text { L. No. } 1700\end{array}$ & $\begin{array}{c}90.19 \\
\pm \\
0.13 \mathrm{c}\end{array}$ & $\begin{array}{c}64.27 \\
\pm \\
0.17 \mathrm{c}\end{array}$ & $\begin{array}{c}40.92 \\
\pm \\
0.20 \mathrm{~b}\end{array}$ & $\begin{array}{c}6.46 \\
\pm 0.15 \\
\text { cd }\end{array}$ & $\begin{array}{c}1.44 \\
\pm \\
0.13 \mathrm{~b}\end{array}$ & $\begin{array}{c}1.32 \\
\pm \\
0.13 \mathrm{~d}\end{array}$ & $\begin{array}{c}0.09 \\
\pm \\
0.01 \mathrm{a}\end{array}$ & $\begin{array}{c}0.10 \\
\pm \\
0.03 \mathrm{c}\end{array}$ & $\begin{array}{c}14.21 \\
\pm \\
0.14 \mathrm{~d}\end{array}$ & $\begin{array}{c}4.00 \\
\pm \\
0.24 \mathrm{e}\end{array}$ & $\begin{array}{c}0.07 \\
\pm \\
0.01 \mathrm{~b}\end{array}$ & $\begin{array}{c}0.04 \\
\pm \\
0.01 \mathrm{~b}\end{array}$ & $\begin{array}{c}0.02 \\
\pm \\
0.02 \mathrm{a}\end{array}$ & $<0.005$ \\
\hline & $\begin{array}{c}123.23 \\
\pm \\
0.27 \mathrm{~d}\end{array}$ & $\begin{array}{c}55.62 \\
\pm \\
0.13 \mathrm{ab}\end{array}$ & $\begin{array}{c}39.79 \\
\quad \pm \\
0.11 \mathrm{~b}\end{array}$ & $\begin{array}{c}6.44 \\
\pm \\
0.17 \mathrm{~cd}\end{array}$ & $\begin{array}{c}2.31 \\
\pm \\
0.12 \mathrm{~g}\end{array}$ & $\begin{array}{c}1.81 \\
\pm \\
0.14 \mathrm{f}\end{array}$ & $\begin{array}{c}0.16 \\
\pm \\
0.01 \mathrm{~d}\end{array}$ & $\begin{array}{c}0.18 \\
\pm \\
0.04 \mathrm{f}\end{array}$ & $\begin{array}{c}20.89 \\
\pm \\
0.20 \mathrm{f}\end{array}$ & $\begin{array}{c}2.99 \\
\pm \\
0.31 \mathrm{~d}\end{array}$ & $\begin{array}{c}0.08 \\
\pm \\
0.01 \mathrm{c}\end{array}$ & $\begin{array}{c}0.04 \\
\pm \\
0.01 \mathrm{~b}\end{array}$ & $\begin{array}{c}0.02 \\
\pm \\
0.04 \mathrm{a}\end{array}$ & $<0.005$ \\
\hline $\begin{array}{l}\text { L. angustifolius } \\
\text { L. No. } 1734\end{array}$ & $\begin{array}{c}118.84 \\
\pm \\
0.23 \mathrm{~d}\end{array}$ & $\begin{array}{c}63.59 \\
\pm \\
0.19 \mathrm{c}\end{array}$ & $\begin{array}{c}45.17 \\
\pm \\
0.15 \mathrm{c}\end{array}$ & $\begin{array}{c}6.40 \\
\pm \\
0.13 \mathrm{c}\end{array}$ & $\begin{array}{c}1.95 \\
\pm \\
0.15 \mathrm{f}\end{array}$ & $\begin{array}{c}1.51 \\
\pm \\
0.21 \mathrm{e}\end{array}$ & $\begin{array}{c}0.09 \\
\pm \\
0.02 \mathrm{a}\end{array}$ & $\begin{array}{c}0.12 \\
\pm \\
0.02 \mathrm{~d}\end{array}$ & $\begin{array}{c}28.49 \\
\pm \\
0.17 \mathrm{~h}\end{array}$ & $\begin{array}{c}6.27 \\
\pm \\
0.19 \mathrm{f}\end{array}$ & $\begin{array}{c}0.08 \\
\pm \\
0.01 \mathrm{c}\end{array}$ & $\begin{array}{c}0.05 \\
\pm \\
0.01 \mathrm{c}\end{array}$ & $\begin{array}{c}0.03 \\
\pm \\
0.04 \mathrm{~b}\end{array}$ & $<0.005$ \\
\hline $\begin{array}{l}\text { L. angustifolius } \\
\text { L. No. } 1800\end{array}$ & $\begin{array}{c}48.68 \\
\pm \\
0.14 \mathrm{~b} \\
\end{array}$ & $\begin{array}{c}54.05 \\
\pm \\
0.23 \mathrm{a} \\
\end{array}$ & $\begin{array}{c}39.95 \\
\pm \\
0.23 \mathrm{~b}\end{array}$ & $\begin{array}{c}6.03 \\
\pm \\
0.06 \mathrm{c}\end{array}$ & $\begin{array}{c}1.40 \\
\pm \\
0.09 \mathrm{~b}\end{array}$ & $\begin{array}{c}0.91 \\
\pm \\
0.09 \mathrm{~b}\end{array}$ & $\begin{array}{c}0.09 \\
\pm \\
0.01 \mathrm{a} \\
\end{array}$ & $\begin{array}{c}0.06 \\
\pm \\
0.02 \mathrm{a} \\
\end{array}$ & $\begin{array}{c}12.95 \\
\pm \\
0.14 \mathrm{c}\end{array}$ & $\begin{array}{c}1.79 \\
\pm \\
0.17 \mathrm{c}\end{array}$ & $\begin{array}{c}0.08 \\
\pm \\
0.01 \mathrm{c}\end{array}$ & $\begin{array}{c}0.04 \\
\pm \\
0.01 \mathrm{~b}\end{array}$ & $\begin{array}{c}0.02 \\
\pm \\
0.01 \mathrm{a}\end{array}$ & $<0.005$ \\
\hline \multicolumn{15}{|c|}{ Statistical analysis } \\
\hline Mean & 95.96 & 60.08 & 43.92 & 6.273 & 1.659 & 1.281 & 0.106 & 0.105 & 17.45 & 3.114 & 0.076 & 0.038 & 0.023 & - \\
\hline d & 40.69 & 7.44 & 8.60 & 0.87 & 0.34 & 0.34 & 0.02 & 0.05 & 7.05 & 2.11 & 0.02 & 0.01 & 0.01 & - \\
\hline $\begin{array}{l}P \text { value } \\
\text { (two tailed) }\end{array}$ & 0.0003 & $<0.0001$ & $<0.0001$ & $<0.0001$ & $<0.0001$ & $<0.0001$ & $<0.0001$ & 0.0004 & 0.0002 & 0.0042 & $<0.0001$ & $<0.0001$ & $<0.0001$ & - \\
\hline $\begin{array}{l}\text { Coefficient of } \\
\text { variation } \%\end{array}$ & 42.40 & 12.39 & 19.58 & 13.89 & 20.83 & 26.51 & 24.09 & 44.38 & 40.42 & 67.79 & 20.96 & 16.54 & 21.79 & - \\
\hline
\end{tabular}

Note. Data expressed as means $(\mathrm{n}=5) \pm \mathrm{SD}$; significant, when $P \leq 0.05$. Values within each group in the same superscript letter are not different at $P \leq 0.05$.

concentration of $\mathrm{Ni}$ in the tested lupine seeds did not exceed the concentrations that the European Food Safety Authority derived as an upper level for the intake of nickel (EFSA, 2006).

Among non-essential elements $\mathrm{Al}, \mathrm{As}, \mathrm{Sr}, \mathrm{Cd}$, $\mathrm{Pb}$ and $\mathrm{Ag}$ were evaluated.

The EFSA has established for the lifelong intake of $\mathrm{Al}$ a tolerable weekly intake of $1 \mathrm{mg}$ per $\mathrm{kg}$ body weight (b.w.) (EFSA, 2008). The least content of Al was observed in the lupine seeds of variety 'Vilčiai' and hybrid line No. 1701 (1.19 and $0.94 \mu \mathrm{g} \mathrm{g}^{-1}$ d.m., respectively) while hybrid lines contained higher content of Al, especially Nos. 1072 and 1734 (6.00 and $6.27 \mu \mathrm{g} \mathrm{g}^{-1}$ d.m., respectively).

The concentration of $\mathrm{Sr}$ in seeds ranged from 9.09 (hybrid line No. 1701) to 26.10 (hybrid line No. 1072) $\mu \mathrm{g} \mathrm{g}^{-1}$ d.m. The concentration of $\mathrm{Ag}$ was found below the detection limit in all lupine seed samples.

$\mathrm{Cd}$ is toxic to a wide range of organs and tissues, and a variety of toxicological endpoints (reproductive toxicity, neurotoxicity, carcinogenicity) have been observed in experimental animals and subsequently investigated in human populations (ATSDR, 2008). However, at a meeting in June 2010, the Joint FAO/WHO Expert Committee on Food Additives (JECFA) withdrew the provisional tolerable weekly intake and established a provisional tolerable monthly intake of $25 \mu \mathrm{g} \mathrm{kg}-1$ b.w. (Joint FAO/WHO Expert Committee..., 2010). A monthly intake was established due to consideration of the long half-life of $\mathrm{Cd}$, and consequently the small to negligible influence of daily ingestion on overall exposure. Concentration of $\mathrm{Cd}$ ranged from 0.026 (hybrid line No. 1701) to 0.049 (hybrid line No. 1734) $\mu \mathrm{g} \mathrm{g}^{-1} \mathrm{~d} . \mathrm{m}$. in lupine seeds.

The concentration of $\mathrm{Pb}$ ranged from 0.06 (hybrid line No. 1701) to 0.11 (hybrid line No. 1072 seeds) $\mu \mathrm{g} \mathrm{g}^{-1}$ d.m. in lupine seeds. In average adult consumers, lead dietary exposure ranges from 0.36 to 1.24 , up to $2.43 \mu \mathrm{g} \mathrm{kg}^{-1}$ body weight (b.w.) per day in high consumers in Europe (EFSA, 2010).

The risk-specific dose of $0.0086 \mu \mathrm{g} \mathrm{kg}^{-1}$ b.w. per day, derived from the As concentration in drinking water determined to represent "negligible risk" $\left(0.3 \mu \mathrm{g} \mathrm{L}^{-1}\right)$ by Canadian agencies (FPTCDW, 2006), is recommended. In the investigated lupine seeds arsenic concentration ranged from 0.015 (No. 1701 seeds) to 0.033 ('Vilčiai' seeds) $\mu \mathrm{g} \mathrm{g}^{-1} \mathrm{~d} . \mathrm{m}$.

The concentration of nonessential elements in the tested lupine seeds was far below the levels that cause a health risk (EFSA, 2006; 2008; FPTCDW, 2006; Joint FAO/WHO Expert Committee..., 2010). 
Results of $A N O V A$ test indicated that variety and hybrid line has a significant effect on $\mathrm{Al}(\mathrm{F}(363.070)=$ 93.559, $p=0.0001), \mathrm{Cr}(\mathrm{F}(22.357)=2.422, p<0.0001)$, $\mathrm{Mn}(\mathrm{F}(90216.207)=34772.709, p<0.0001), \mathrm{Fe}$ $(\mathrm{F}(4508.221)=1164.079, p=0.0001), \mathrm{Co}(\mathrm{F}(10.218)=$ $0.046, p=0.0001), \mathrm{Ni}(\mathrm{F}(26.274)=2.506, p=0.0001)$, $\mathrm{Cu}(\mathrm{F}(118.689)=15.931, p=0.0001), \mathrm{Zn}(\mathrm{F}(7794.620)$ $=1553.663, p=0.001), \operatorname{Se}(\mathrm{F}(10.759)=0.014, p=0.001)$ and $\mathrm{Sr}(\mathrm{F}(6341.740)=1044.511, p<0.0001)$ content in lupine seeds. Therefore, significant effect of variety and hybrid line on $\mathrm{As}, \mathrm{Cd}$ and $\mathrm{Pb}$ content in lupine seeds was not found.

\section{Conclusions}

1. The content of alkaloids in the seeds of lupine varieties 'Vilčiai' and 'Vilniai' was $0.021 \%$ and $0.030 \%$, respectively; while in the new hybrid lines of Lupinus angustifolius the content of alkaloids was lower and varied from $0.011 \%$ to $0.012 \%$.

2. The concentration of $\mathrm{Mg}$ and $\mathrm{K}$ in the seeds of L. luteus L. variety 'Vilčiai' was higher (3.44 and $13.91 \mathrm{~g} \mathrm{~kg}^{-1}$ d.m., respectively) in comparison with L. angustifolius variety 'Vilniai' (2.00 and $12.63 \mathrm{~g} \mathrm{~kg}^{-1}$ d.m., respectively). Higher contents of $\mathrm{Ca}$ and $\mathrm{Na}$ were detected in the seeds of hybrid lines Nos. 1700, 1701, $1703,1072,1734$ and 1800 (varied in range 1.65-2.41 and 1.01-1.19 $\mathrm{g} \mathrm{kg}^{-1}$ d.m., respectively) in comparison with $L$. luteus variety 'Vilčiai' and L. angustifolius variety 'Vilniai'. Among the L. angustifolius hybrid lines the highest content of $\mathrm{Mg}$ and $\mathrm{K}$ was determined in the seeds of line No. 1700 (2.48 and $13.61 \mathrm{~g} \mathrm{~kg}^{-1} \mathrm{~d} . \mathrm{m}$., respectively).

3 . The highest energy value was established in the seeds of hybrid line No. 1734 (382 kcal $100 \mathrm{~g}^{-1}$ seeds).

4. The dominant fatty acids in the seeds of L. luteus variety 'Vilčiai', L. angustifolius variety 'Vilniai' and hybrid lines are unsaturated fatty acids oleic (C18:1) and linoleic (C18:2) (an average content, respectively, $33.2 \%$ and $38.4 \%$ of the total content of fatty acid). The seeds of the six hybrid lines of L. angustifolius Nos. 1700, 1701, 1703, 1072, 1734 and 1800 had higher content of oleic and linoleic acids compared with the L. angustifolius variety 'Vilniai'.

5. Higher carbohydrate content was observed in the seeds of the L. luteus variety 'Vilčiai' $(41.6 \%)$ compared with the L. angustifolius variety 'Vilniai' $(49.3 \%)$, whereas in the seeds of the two hybrid lines Nos. 1701 and 1800 the content of carbohydrates was higher (50.2\% and 50.8\%, respectively).

Received 16072015 Accepted 14012016

\section{References}

Alsafwah S., LaGuardia S. P., Arroyo M., Dockery B. K., Bhattacharya S. K., Ahokas R. A., Newman K. P. 2007. Congestive heart failure is a systemic illness: a role for minerals and micronutrients. Clinical Medicine and Research, 5 (4): 238-243 http://dx.doi.org/10.3121/cmr.2007.737

ATSDR. 2008. Toxicological profile for cadmium. Draft. Agency for Toxic Substances and Disease Registry, United States Department of Health and Human Services
Bartkiene E., Schleining G., Rekstyte T., Krungleviciute V., Juodeikiene G., Vaiciulyte-Funk L., Maknickiene Z. 2013. Influence of the addition of lupin sourdough with different lactobacilli on dough properties and bread quality. International Journal of Food Science and Technology, 48 (12): $2613-2620$ http://dx.doi.org/10.1111/ijfs. 12257

DRI. 2005. Dietary reference intakes for water, potassium, sodium, chloride, and sulfate. http://www.nap.edu/ catalog/10925.html

EFSA. 2006. Tolerable upper intake levels for vitamins and minerals. European Food Safety Authority, Parma, Italy

EFSA. 2008. Safety of aluminium from dietary intake. Scientific opinion of the panel on food additives, flavourings, processing aids and food contact materials (AFC). The EFSA Journal, 754: 3-34

EFSA. 2010. Scientific opinion on lead in food. EFSA panel on contaminants in the food chain (CONTAM). EFSA Journal, 8 (4): 1570

Ehsan M., Molumeli A. P., Espinosa H. V., Baeza R. A., Perez M. J., Soto H. M., Ojeda T. E., Jaen C. D., Ruiz B. A., Robledo S. E. 2007. Contamination time effect on plant available fractions of $\mathrm{Zn}$ and $\mathrm{Cd}$ in a Mexican clay loam soil. Journal of Applied Sciences, 7 (16): 2380-2384 http://dx.doi.org/10.3923/jas.2007.2380.2384

Ehsan M., Viveros F. M. L., Hernandez V. E., Barakat M. A., Ortega A. R., Maza A. V., Monter J. V. 2015. Zinc and cadmium accumulation by Lupinus uncinatus Schldl. grown in nutrient solution. International Journal of Environment Science and Technology, 12 (1): 307-316 http://dx.doi.org/10.1007/s13762-013-0456-0

Erbas M. 2010. The effects of different debittering methods on the production of lupin bean snack from bitter Lupinus albus L. seeds. Journal of Food Ouality. 33 (6): 742-757 http://dx.doi.org/10.1111/j.1745-4557.2010.00347.x

Esteban E., Moreno E., Penalosa J., Cabrero J. I., Millan R., Zornoza P. 2008. Short and long-term uptake of $\mathrm{Hg}$ in white lupin plants: kinetics and stress indicators. Environmental and Experimental Botany. 62 (3): 316-322 http://dx.doi.org/10.1016/j.envexpbot.2007.10.006

FPTCDW. 2006. Guidelines for Canadian drinking water quality. Guideline technical document: arsenic. FederalProvincial-Territorial Committee on Drinking Water, Canada

Hudson B. J. F. 1979. The nutritional quality of lupin seed. Oualitas Plantarum. 29 (1-2): 245-251 http://dx.doi.org/10.1007/BF02590278

Hung T. V., Handson P. D., Amenta V. C., Kyle W. S. A., Yu R. S. T. 1987. Content and distribution of manganese in lupin seed grown in Victoria and in lupin flour, spraydried powder and protein isolate prepared from the seeds. Journal of the Science of Food and Agriculture, 41 (2): 131-139 http://dx.doi.org/10.1002/jsfa.2740410206

Joint FAO/WHO Expert Committee on Food Additives. 2010. Summary and conclusions. Food and Agriculture Organization of the United Nations, World Health Organization, Geneva

Krejpcio Z., Lampart-Szczapa E., Suliburska J., Wójciak R. W., Hoffmann A. 2006. A study on release of selected minerals from lupine seeds in in vitro enzymatic digestion. Polish Journal of Environmental Studies, 15 (2): 121-123

Kumar B. S., Priyadarsini K. I. 2014. Selenium nutrition: how important is it? Biomedicine and Preventive Nutrition, $4(2): 333-341$ http://dx.doi.org/10.1016/j.bionut.2014.01.006

Maknickienè Z., Ražukas A. 2007. Narrow-leaved forage lupine (Lupinus angustifolius L.) breeding aspects. Žemès ùkio mokslai, 14 (3): 27-31

Maknickiene Z., Asakaviciute R., Baksiene E., Razukas A. 2013. Alkaloid content variations in Lupinus luteus L. and Lupinus angustifolius L. Archives of Biological Sciences, 65 (1): $107-112$ http://dx.doi.org/10.2298/ABS1301107M 
Martínez-Villaluenga C., Frías J., Vidal-Valverde C. 2006. Functional lupin seeds (Lupinus albus L. and Lupinus luteus L.) after extraction of $\alpha$-galactosides. Food Chemistry. 98 (2): 291-299 http://dx.doi.org/10.1016/j.foodchem.2005.05.074

Nwokolo E., Smartt J. 1996. Food and feed from legumes and oilseeds ( $1^{\text {st }}$ ed. $)$ http://dx.doi.org/10.1007/978-1-4613-0433-3

Porres J. M., Aranda P., López-Jurado M., Urbano G. 2007. Nitrogen fractions and mineral content in different lupin species (Lupinus albus, Lupinus angustifolius, and Lupinus luteus). Changes induced by the r-galactoside extraction process. Journal of Agricultural and Food Chemistry, 55 (18): 7445-7452 http://dx.doi.org/10.1021/jf070718z

Shah F., Kazi T. G., Afridi H. I., Kazi N., Baig J. A., Shah A. Q., Khan S., Kolachi N. F., Wadhwa S. K. 2011. Evaluation of status of trace and toxic metals in biological samples (scalp hair, blood, and urine) of normal and anemic children of two age groups. Biological Trace Element Research, $141(1-3): 131-149$

http://dx.doi.org/10.1007/s12011-010-8736-8

Trace elements in human nutrition and health. 1996. World Health Organization, Geneva, Switzeland
Uzun B., Arslan C., Karhan M., Toker C. 2007. Fat and fatty acids of white lupin (Lupinus albus L.) in comparison to sesame (Sesamum indicum L.). Food Chemistry, 102 (1): 45-49 http://dx.doi.org/10.1016/j.foodchem.2006.03.059

Vazquez S., Agha R., Granado A., Sarro M. J., Esteban E., Penalosa J. M., Carpena R. O. 2006. Use of white lupin plant for phytostabilization of $\mathrm{Cd}$ and As polluted acid soil. Water Air and Soil Pollution. 177 (1-4): 349-365 http://dx.doi.org/10.1007/s11270-006-9178-y

Williams M. 2006. Dietary supplements and sports performance: metabolites, constituents, and extracts. Journal of the International Society of Sports Nutrition. 3 (2): 1-5 http://dx.doi.org/10.1186/1550-2783-3-2-1

Ximenez-Embun P., Madrid-Albarran Y., Camara C., Cuadrado C., Burbano C., Muzquiz M. 2001. Evaluation of Lupinus species to accumulate heavy metals from waste waters. International Journal of Phytoremediation, 3 (4): 369-379 http://dx.doi.org/10.1080/15226510108500065

Zelalem K. A., Chandravanshi B. S. 2014. Levels of essential and non-essential elements in raw and processed Lupinus albus L. (white lupin, gibto) cultivated in Ethiopia. African Journal of Food, Agriculture, Nutrition and Development, 14 (5): 2015-2035

ISSN 1392-3196 / e-ISSN 2335-8947

Zemdirbyste-Agriculture, vol. 103, No. 1 (2016), p. 107-114

DOI 10.13080/z-a.2016.103.014

\title{
Lupinus luteus $\mathrm{L}$., L. angustifolius $\mathrm{L}$. bei $L$. angustifolius $\mathrm{L}$. hibridų sėklų cheminè sudėtis ir mitybinè vertè
}

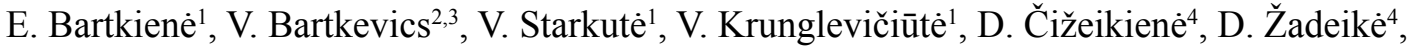 \\ G. Juodeikiené ${ }^{4}$, Z. Maknickiené 5
}

${ }^{1}$ Lietuvos sveikatos mokslų universitetas

${ }^{2}$ Latvijos universitetas

${ }^{3}$ Latvijos maisto saugos, gyvūnų sveikatos ir aplinkos institutas

${ }^{4}$ Kauno technologijos universitetas, Lietuva

${ }^{5}$ Lietuvos agrarinių ir miškų mokslų centro Vokès filialas

\section{Santrauka}

Tyrimo tikslas - ištirti geltonžiedžio lubino (Lupinus luteus L.) veislès 'Vilčiai' bei siauralapio lubino (L. angustifolius L.) veislès 'Vilniai' ir siauralapio lubino (L. angustifolius L.) šešių naujų hibridu Nr. 1700, 1701, 1703, 1072, 1734 bei 1800, išvestų Lietuvoje, sèklų cheminę sudètị, mitybinę vertę, riebalų rūgščių sudètị, makroir mikroelementų kiekį. Taikant dujų chromatografijos su liepsnos jonizacijos detektoriumi metodą lubinų sèklose daugiausia buvo nustatyta nesočiųjų oleino ir linolo riebalų rūgščių, vidutiniškai 33,2 ir 38,4 \% bendro riebalų rūgščiu kiekio, o sočiųju riebalų rūgščių buvo nustatyta gerokai mažiau. Didžiausias baltymų kiekis, įvertintas Kjeldalio metodu, buvo nustatytas veislès 'Vilčiai' lubinų sẻklose $(40,8 \%)$, o lubinų veislès 'Vilčiai' sẻklose ir hibriduose baltymu kiekis buvo nuo 20,1 iki 25,7 \% mažesnis. Ekstrahuojant su heksanu mažiausias riebalu kiekis buvo veislès 'Vilčiai' lubinų sẻklose $-4,4 \%$, o lubinų veislès 'Vilčiai' sẻklose ir hibriduose riebalų kiekis buvo nuo 18,2 iki 59,1 \% didesnis. Angliavandeniu didžiausias kiekis buvo Nr. 1800 hibridu sėklose (50,8\%), mažiausias - veislès 'Vilčiai' sėklose (41,6\%). Alkaloidų kiekis siauralapio lubino (L. angustifolius L.) naujai išvestų hibridų sėklose buvo 0,011-0,012\%, o veisliu 'Vilniai' ir 'Vilčiai' lubinu sẻklose jis sudare 0,030 ir $0,021 \%$. Lubinu sėklu mikro- ir makromineralinių medžiagų analizè, atlikta taikant induktyviai susietos plazmos masių spektrometriją, parodè, kad didžiausias kiekis natrio (Na) buvo nustatytas naujai išvestų lubinų hibridų (nuo 1,07 iki $1,19 \mathrm{mg} \mathrm{g}^{-1}$ sausụjų medžiagų), didžiausi kiekiai magnio $(\mathrm{Mg})$ ir kalio $(\mathrm{K})$ - veislès 'Vilčiai' (atitinkamai 3,44 ir 13,9 mg g-1 sausujjų medžiagų) sẻklose. Didžiausi kiekiai Mg nustatyti L. angustifolius naujai išvestų hibridų sẻklose. Be to, didžiausias kiekis biologiškai svarbių mikromineralinių medžiagų Mn, Fe, Zn ir Se buvo nustatytas veislès 'Vilčiai' sėklose, atitinkamai $147,65,73,52,59,84$ ir $0,13 \mu \mathrm{g} \mathrm{g}^{-1}$ sausujų medžiagų. Lubinų sẻklose biologiškai nesvarbių (neesminių) mineralinių elementų koncentracija nustatyta gerokai mažesnè už pavojų sveikatai sukeliantị kiekį.

Reikšminiai žodžiai: induktyviai susietos plazmos masių spektrometrija, lubinai, mitybinė vertė, makro- ir mikroelementai, riebalų rūgštys.

Please use the following format when citing the article:

Bartkienė E., Bartkevics V., Starkutė V., Krunglevičiūtė V., Čižeikienė D., Žadeikė D., Juodeikienė G., Maknickienė Z. 2016. Chemical composition and nutritional value of seeds of Lupinus luteus, L. angustifolius and new hybrid lines of L. angustifolius. Zemdirbyste-Agriculture, 103 (1): 107-114 DOI 10.13080/z-a.2016.103.014 